DOI: 10.25140/2411-5215-2021-1(25)-117-126

\author{
Наталія Холявко, Марія Колоток
}

\title{
ІНФОРМАЦЙНІ ТЕХНОЛОГІЇ В РОБОТІ ЗАРУБІЖНИХ ФІНАНСОВИХ УСТАНОВ
}

\author{
Nataliia Kholiavko, Mariia Kolotok \\ INFORMATION TECHNOLOGIES IN THE ACTIVITIES \\ OF FOREIGN FINANCIAL INSTITUTIONS
}

На сьогодні інформаиійно-комунікаиійні технології вже не являють собою інновацію; до того ж у період пандемії коронавірусу такі технології почали активно використовуватись різноманітними компаніями в усьому світі. У сучасних умовах посилення конкурентної боротьби на ринку фінансові установи вимушені активно впроваджувати нові інформачійні технології, запускати інноваційні послуги, удосконалювати наявні механізми надання фінансових послуг. Стаття спрямована на дослідження світового досвіду використання інформаиійних технологій у роботі фінансових установ та ідентифікацію кращих світових практик для подальшого визначення перспектив їх впровадження в Україні. Проаналізовано досвід країн Європейського Союзу (зокрема, Німеччини, Великої Британії, Іспанії, Швеиії, Швейиарії), Сполучених Штатів Америки, Японії та Китаю в застосуванні їх фінансовими інститутами новітніх технологій; визначено вплив інформаційно-комунікаційних технологій на ефективність роботи окремих фінансових установ зазначених краӥн. Автори доходять висновку, щэо впровадження інформаџійних технологій у діяльність фінансових установ забезпечує провідним краӥнам світу можливість утримання високих місиь у світових рейтингах і високих конкурентних позицій на міжнародному ринку фінансових послуг. Серед перспектив подальших досліджень визначено проблему забезпечення кібербезпеки, що вимагає формування дієвих механізмів протидії кібератакам, а також розробки інноваційних інформаційних технологій захисту фінансових систем та інформації про суб'єктів ринку фінансових послуг.

Ключові слова: інформачійні технології; фінансові установи; онлайн-банкінг; штучний інтелект; blockchain; Big Data; фінансові послуги.

Табл.: 3. Рис.: 1. Бібл.: 33.

Today, information and communication technologies are no longer an innovation; moreover, during the coronavirus pandemic, such technologies began to be actively used by various companies around the world. In modern conditions of intensification of competition in the market, financial institutions are forced to actively introduce new information technologies, launch innovative services, improve existing mechanisms for providing financial services. The article is aimed at studying the world experience of using information technologies in the work of financial institutions. and identifying the best world practices in order to further determine the prospects for their implementation in Ukraine. The authors analyze the experience of the European Union (in particular, Germany, Great Britain, Spain, Sweden, Switzerland), the United States, Japan and China in the use of the latest technologies by their financial institutions; the influence of information and communication technologies on the efficiency of certain financial institutions of these countries is determined. The authors conclude that the introduction of information technology in the activities of financial institutions provides the world's leading countries with the opportunity to maintain high rates in world rankings, and high competitive positions in the international financial services market. The article highlights the prospects for further research, namely the problem of cyber security, solving of which requires the development of effective mechanisms to combat cyber-attacks, as well as the development of innovative information technologies to protect financial systems and information about financial services market participants.

Keywords: information technologies; financial institutions; online banking; Artificial Intelligence; blockchain; Big Data; financial services.

Table: 3. Fig.: 1. References: 33.

JEL Classification: G20

Постановка проблеми. Сучасна економіка наскрізь пронизана інформаційними технологіями. Уже практично неможливо уявити ефективне функціонування практично будь-якої сфери суспільного життя без застосування інформаційно-комунікаційних технологій, оскільки вони дозволяють оптимізувати процеси, підвищити їхню оперативність, дають змогу зберігати й обробляти великі обсяги інформації, проводити більш точні розрахунки, швидко передавати інформацію та забезпечити її точність, прозорість і надійність тощо.

Останнє десятиліття характеризується особливо високими темпами розвитку технологічних інновацій та масштабами трансформації національних економік під їх впливом. Створення нових мов програмування, платформ для операційних систем, роботів

(C) Холявко Н. І., Колоток М. О., 2021 
докорінно змінює засади ведення бізнесу. Ці зміни не оминули і фінансовий сектор, у межах якого спостерігається активізація діяльності з впровадження проєктів, орієнтованих на розробку на базі інноваційних інформаційних технологій нових фінансових продуктів та послуг, а також забезпечення більш надійного програмного збереження інформації і захисту її від кібератак.

Провідні держави світу накопичили чималий досвід застосування інформаційних технологій у роботі фінансових установ, у тому числі в напрямі захисту від витоку інформації, підвищення рівня іiі транспарентності, модернізації механізмів надання фінансових послуг. Позитивний досвід економічно розвинених країн може виявитись цінним для вітчизняних фінансових інституцій, а його імплементація у практику їхньої діяльності сприятиме підвищенню рівня конкурентоспроможності на ринку фінансових послуг і рівня довіри населення до банківських установ. Вищезазначене обгрунтовує актуальність теми цього дослідження.

Аналіз останніх досліджень і публікацій. Тема використання інформаційних технологій у роботі фінансових установ $\epsilon$ актуальною як для науковців, так і для фінансистів-практиків та експертів-аналітиків. Це знайшло свій прояв у великій кількості фахових публікацій, зокрема слід виокремити роботи О. Любіча, В. Плескач, Т. Затонацької, Є. Поліщук, Г. Поченчук та інших вітчизняних учених. 3-поміж закордонних науковців, які досліджують питання використання фінансових технологій, варто відзначити Дж. В. Дейн, М. Міллер, Х. Мінскі, Й. Блах тощо.

Виділення недосліджених частин загальної проблеми. Проведений огляд літературних джерел засвідчив достатньо глибоку опрацьованість теми впровадження інформаційних технологій у роботу фінансових установ. Водночас висока динамічність фінансового сектору, швидкі темпи науково-технічного й інноваційного розвитку зумовлюють необхідність постійного моніторингу поточного стану й перспектив імплементації фінансових технологій, особливостей їх використання для вдосконалення існуючих і якісного надання нових фінансових послуг у різних країнах світу.

Метою статті є вивчення світового досвіду використання інформаційних технологій у роботі фінансових установ та ідентифікація кращих світових практик для подальшого визначення перспектив їх впровадження в Україні.

Виклад основного матеріалу. Глобалізаційні процеси формують сукупність нових викликів до фінансових установ. Утримання високих конкурентних позицій на світовому ринку фінансових послуг вимагає динамічності, гнучкості й інноваційності діяльності банків та фінансово-кредитних установ. Одним із потужних інструментів конкурентної боротьби стають інформаційні технології, спроможні спростити та прискорити комунікацію суб'єктів ринку, згенерувати інноваційні продукти, вдосконалити підходи до надання фінансових послуг та забезпечити безпеку інформації (рис. 1). У межах цієї статті нами систематизовано досвід деяких країн світу в застосуванні інформаційних технологій у роботі фінансових установ.

Банками країн Свропейського Союзу витрачаються чималі бюджети на апробацію та впровадження інноваційних інформаційно-комунікаційних технологій, реалізацію заходів із протидії кібератакам і підвищення рівня безпечності інформації. Практично всі європейські банки оперативно запровадили мобільний банкінг (електронну систему, що дозволяє через додаток у мобільному телефоні виконувати низку банківських операцій - грошові перекази, оформлення кредитів, відкриття депозитних рахунків тощо) і перебувають у пошуку нових додатків та опцій для такої системи. Стисла характеристика діяльності компаній деяких країн $\mathrm{CC}$, що активно використовують у своїй діяльності інноваційні фінансові технології, наведена в табл. 1. 


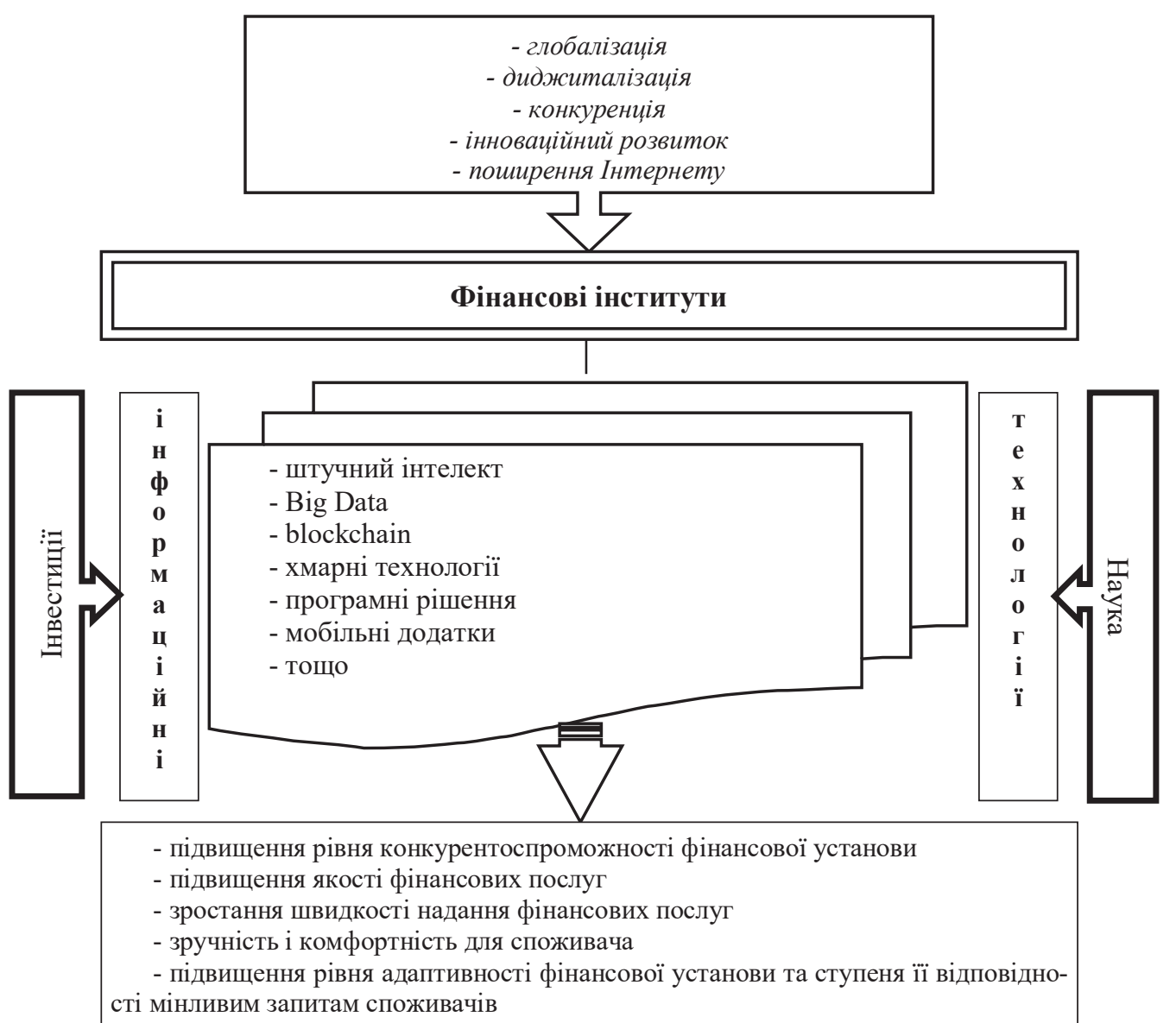

Рис. 1. Чинники та переваги впровадження інформаційних технологій у роботу фінансових установ

Джерело: побудовано авторами.

Таблиця 1

Характеристика діяльності провідних FinTесh-компаній Свропейського Союзу

\begin{tabular}{|c|c|c|}
\hline $\begin{array}{c}\text { Назва } \\
\text { компанії }\end{array}$ & Країна & Масштаби діяльності \\
\hline Adyen & Нідерланди & $\begin{array}{l}\text { У період з } 2015 \text { по } 2019 \text { рр. дохід Adyen зріс із 98,5 млн до 496,9 млн } \\
\text { дол. США }\end{array}$ \\
\hline Nexi & Італія & $\begin{array}{l}\text { Спеціалізується на платіжних системах, таких як Nexi Payments, на- } \\
\text { полягаючи на тому, що сучасні технології витіснили готівкові платежі }\end{array}$ \\
\hline Klarna & Швеція & $\begin{array}{l}\text { Один із найбільших банків СС, який надає платіжні рішення для } \\
85 \text { млн споживачів у } 17 \text { країнах }\end{array}$ \\
\hline Greensill & Велика Британія & $\begin{array}{l}\text { Забезпечує клієнтів фінансовим ланцюгом поставок у Свропі, Півні- } \\
\text { чній Америці, Латинській Америці, Африці та Азії }\end{array}$ \\
\hline Transferwise & Велика Британія & $\begin{array}{l}\text { Цифрові грошові перекази компанії використовує понад } 10 \text { млн осіб } \\
\text { по всьому світу }\end{array}$ \\
\hline N26 & Німеччина & Функціонує на 24 європейських ринках та нараховує 2,3 млн клієнтів \\
\hline $\begin{array}{l}\text { Oaknorth } \\
\text { Bank }\end{array}$ & Велика Британія & $\begin{array}{l}\text { Співпрацює з перспективними банками з усього світу з орієнтацією } \\
\text { на задоволення потреб сотень тисяч підприємств }\end{array}$ \\
\hline Monzo & Велика Британія & $\begin{array}{l}\text { Має досить високу популярність у світі та нараховує понад } 2 \text { млн } \\
\text { клієнтів (передусім за рахунок того, що гарантує утричі безпечніший } \\
\text { захист персональних даних клієнтів і в чотири рази ефективнішу бо- } \\
\text { ротьбу з шахрайством порівняно з іншими банками країни) }\end{array}$ \\
\hline $\begin{array}{l}\text { Funding } \\
\text { Circle }\end{array}$ & Велика Британія & $\begin{array}{l}\text { Має попит у малого бізнесу в усьому світі; нараховує понад } 90000 \\
\text { клієнтів }\end{array}$ \\
\hline Izettle & Швеція & $\begin{array}{l}\text { Поширена в кранах СС і Латинської Америки торговельна платформа } \\
\text { для малого бізнесу }\end{array}$ \\
\hline
\end{tabular}

Джерело: складено авторами на основі [1-6]. 
Протягом останніх років у Німеччині фінансові установи застосовують опцію відеокамери (VTM), за допомогою якої клієнт через мобільний телефон або інший гаджет може отримати особисту консультацію представника банку з будь-якого питання. Така комунікація суттєво скорочує витрати часу споживача фінансових послуг та спрощує для працівника банку ідентифікацію клієнта [7]. Поширеною також стала послуга передачі звукових даних (NSDT), яка дозволяє споживачу при здійсненні операції для підтвердження, замість стандартного одноразового пароля, просто відтворити надісланий банком звук [7]. Така технологія працює навіть в умовах шумного оточення, що робить iii зручною і застосовною за різних обставин, в яких може перебувати клієнт.

Чільне місце серед інформаційних технологій, які активно використовуються в роботі фінансових установ, посідає Big Data. Ця технологія дозволяє прискорити процеси збору та аналізу інформації, удосконалити контроль над системами інформаційної безпеки і захисту від шахрайства. На основі технології Big Data комерційний банк Великої Британії NatWest створив цифровий сервіс Mettle для малого бізнесу [8]; за використання штучного інтелекту та аналітики Big Data розробив додаток Mimo з обліку особистих коштів [9]; запустив цифрового асистента Cora в онлайн-банкінг для надання клієнтам інформації з більш ніж 200 запитань [8].

Однією із перших серед європейських країн інноваційну інформаційну технологію blockchain реалізувала банківська група Grupo Santander (Iсnанія). Застосування такої технології в роботі фінансових установ дозволяє суттєвим чином прискорити процеси переказу грошей, здійснювати їх без посередників та забезпечити транспарентність проведення операцій. Технологію blockchain покладено в основу розробленої групою Santander платіжної системи One Pay FX, роботу якої спрямовано на оптимізацію платежів між Свропою та Південною Америкою [9].

Поступового поширення набуває застосування роботів у діяльності фінансових установ. Власне, це $є$ певна інженерна розробка, механізм із прописаним фахівцем спеціальним набором команд, що загалом станом на сьогодні не $\epsilon$ інновацією, однак протягом останніх років набуває нових форм прояву та напрямів застосування. Впровадження роботів дозволяє банкам економити на витратах праці касирів та інших фахівців, які виконують рутинну, монотонну, одноманітну технічну роботу.

У цьому контексті доречно згадати про банк Nordea Bank AB (Швеція), що заявляє про прагнення замінити на роботів весь наявний персонал. Навіть перші кроки з реалізації такої ідеї дозволили суттєво скоротити витрати, а в недалекому майбутньому планується повністю замінити роботами операторів телекомунікаційного зв'язку, а також організувати процеси керування активами банку на основі потужностей сучасних роботів [10].

Окремої уваги потребує кейс швейцарського банку St. Galler Kantonalbank, у якому комунікація з клієнтами, вирішення їхніх питань, надання допомоги в проведенні операцій здійснюється роботами, тобто, по суті, вони заміщають деякі функції оператора, касира, менеджера. Крім цього, роботами ведеться бухгалтерська звітність [11].

Колосальний досвід у застосуванні роботів мають американські фінансові установи (табл. 2). Наприклад, банківська установа JPMorgan Chase (США) використовує робота Persado як копірайтера. Технічні можливості цього робота дозволяють швидко створювати різні варіанти напису текстів, а також за необхідності переписувати їх [12]. Варто відзначити, що згадана вище JP Morgan Chase була однією із перших установ, яка почала зберігати дані у хмарному сховищі Amazon Cloud [13]. Така хмарна інфраструктура відповідає нормам чинного законодавства країни, забезпечує вищу безпеку й конфіденційність інформації. Уже станом на 2020 р. близько 90 \% американських банків успішно перейшли на цю технологію. 
ФІНАНСОВІ РЕСУРСИ: ПРОБЛЕМИ ФОРМУВАННЯ ТА ВИКОРИСТАННЯ

Аналогічно до практики запровадження хмарної інфраструктури, глибоко інтегрованим в роботу фінансових установ США $є$ електронний банкінг. У середньому щорічний приріст чисельності користувачів е-банкінгу становить $20 \%$ [14], а деякі банки країни (EverBank Direct, PerkStreet Financil, BankSimple, Bank of Internet USA) здійснюють перехід на використання лише інтернет-банкінгу при наданні повного спектра банківських послуг (відкриття рахунку, проведення грошових переказів, обмін валюти, отримання кредитів, вкладення депозитів, операції на фондовому ринку тощо) [15].

Характеристика діяльності провідних FinTесh-компаній США

\begin{tabular}{|c|c|c|}
\hline Назва & Масштаби діяльності & Характеристика діяльності \\
\hline 1 & 2 & 3 \\
\hline Stripe & $\begin{array}{l}\text { Клієнти варіюються від невеликих } \\
\text { вебсайтів до Amazon та Facebook. }\end{array}$ & $\begin{array}{l}\text { У } 2019 \text { році Stripe запустила нову корпоративну } \\
\text { кредитну картку та позики для малого бізнесу, } \\
\text { які автоматично погашаються за рахунок плате- } \\
\text { жів, які вона обробляє для позичальників }\end{array}$ \\
\hline Ripple & $\begin{array}{l}\text { Серед клієнтів має транснаціональну } \\
\text { корпорацію Standard Chartered та фінан- } \\
\text { сово-кредитну групу Santander. У } 2019 \text { р. } \\
\text { продано XRР на } 500 \text { млн дол. США } \\
\end{array}$ & $\begin{array}{l}\text { Система, яка за допомогою технології блокчейн } \\
\text { сприяє здійсненню міжнародних платежів, у тому } \\
\text { числі за допомогою криптовалюти }\end{array}$ \\
\hline Coinbase & $\begin{array}{l}\text { Кількість клієнтів біржі становить бли- } \\
\text { зько } 25 \text { млн осіб }\end{array}$ & $\begin{array}{l}\text { Пропонує послуги зберігання криптографічних } \\
\text { даних установам. Розробляє особистий гаманець } \\
\text { та нові валюти, призначені для тих, хто прагне } \\
\text { більшої конфіденційності } \\
\end{array}$ \\
\hline Robinhood & $\begin{array}{l}\text { Станом на } 2020 \text { р. кількість клієнтів ста- } \\
\text { новила понад } 10 \text { млн осіб }\end{array}$ & $\begin{array}{l}\text { Мобільний додаток, який пропонує торгівлю ак- } \\
\text { ціями, ETF, опціонами та криптовалютами без } \\
\text { комісій }\end{array}$ \\
\hline Chime & Має близько 12 млн клієнтів & $\begin{array}{l}\text { Банк, що працює лише для мобільних пристроїв, } \\
\text { не має банківської ліцензії, але використовує ре- } \\
\text { сурси та інфраструктуру великих банків. Пропо- } \\
\text { нує безкоштовні чекові рахунки з можливістю } \\
\text { автоматичного округлення покупок та внесення } \\
\text { змін на ощадні рахунки }\end{array}$ \\
\hline Plaid & $\begin{array}{l}\text { Кількість клієнтів у } 2019 \text { р. збільшилася } \\
\text { вдвічі до } 2600 \text { осіб, при цьому розшири- } \\
\text { вшись на територію Великобританії, Іс- } \\
\text { панії, Франції та Ірландії }\end{array}$ & $\begin{array}{l}\text { Пов’язує платіжні програми (Square Cash) та про- } \\
\text { грами для особистих фінансів (Acorns) з банківсь- } \\
\text { кими рахунками користувачів для переказу і відс- } \\
\text { теження коштів. Інтеграція Plaid відповідає PSD2, } \\
\text { цим самим забезпечуючи додаткову надійність } \\
\text { доступу до європейської фінансової екосистеми }\end{array}$ \\
\hline SoFi & Налічує понад 850000 учасників & $\begin{array}{l}\text { Пропонує такі фінансові послуги: особисті пози- } \\
\text { ки, іпотечні кредити, страхування, чекові рахун- } \\
\text { ки, заощадження та інвестування }\end{array}$ \\
\hline $\begin{array}{l}\text { Credit } \\
\text { Karma }\end{array}$ & $\begin{array}{l}\text { Чисельність клієнтів становить } 50 \text { млн } \\
\text { осіб }\end{array}$ & $\begin{array}{l}\text { Безкоштовна послуга моніторингу та оцінки кре- } \\
\text { дитних балів }\end{array}$ \\
\hline Opendoor & Близько 1,3 млн клієнтів & $\begin{array}{l}\text { FinTech-компанія у сфері нерухомості, націлена } \\
\text { на кардинальну трансформацію способів прода- } \\
\text { жу клієнтами будинків і споруд }\end{array}$ \\
\hline Root & $\begin{array}{l}\text { Має ліцензію функціонування в } 36 \text { шта- } \\
\text { тах США }\end{array}$ & $\begin{array}{l}\text { Забезпечує автострахування, кваліфікує клієнтів } \\
\text { та встановлює їхні страхові тарифи. Може конт- } \\
\text { ролювати водіння за допомогою програми для } \\
\text { смартфона, що працює на основі вимірювання } \\
200 \text { змінних. Нещодавно розширила свою діяль- } \\
\text { ність на страхування орендарів, пропонуючи по- } \\
\text { крити втрати їхнього майна }\end{array}$ \\
\hline
\end{tabular}

Джерело: складено авторами на основі [16-20]. 
Необхідно також зауважити вагомий досвід фінансових установ Японії у використанні інформаційних технологій. Стрімкий розвиток останніх у країні забезпечує оперативну і докорінну трансформацію фінансового сектору, а також створює підгрунтя для лідерства країни на міжнародній арені. До прикладу, одним із перших у світі саме японський банк Ogaki Kyoritsu виступив із ініціативою запустити абсолютно нові банкомати, що не потребують фізичного використання пластикової картки, а для ідентифікації клієнта використовують його біометричні дані [21]. Сьогодні така технологія вже стала звичною практикою для низки банків Японії.

Активно у своїй діяльності технологіями штучного інтелекту користується японська страхова компанія Fukoku Mutual Life Insurance. Зокрема, вона застосовує програму Watson Explorer AI від IBM, яка дозволяє проаналізувати дані медичних полісів по операціях та процедурах і, відповідно, правильно розрахувати розмір страхових виплат. У підсумку, застосування такої технології створює для компанії можливість підвищити свою продуктивність на 30 \% [22].

Одним із найбільш потужних гравців на світовому ринку фінансових послуг є Кumaй (табл. 3). У 2018 році фінансові компанії цієї країни інвестували в штучний інтелект близько 23 млрд доларів США [23]. Серед найбільш знакових інноваційних розробок слід зазначити: технологію Eye to God, впровадження якої в термінали самообслуговування дозволило спростити операції розпізнавання облич, зчитування відбитків пальців; технологію Yuncong, яка, на відміну від Еуe to God, використовує комп'ютерний зір і завдяки цьому робить процес оплати більш легким та надійним; систему перевірки документів Qunzhi, що використовує технології NLP, графи знань, OCR, які забезпечують вищу точність перевірки і дозволяють знизити навантаження на персонал фінансових установ [24].

Таблиця 3

Характеристика провідних FinTесh -компаній Китаю

\begin{tabular}{|c|c|c|}
\hline $\begin{array}{c}\text { Назва } \\
\text { компанії }\end{array}$ & Характеристика компанії & Особливості діяльності \\
\hline 1 & 2 & 3 \\
\hline Ant Group & $\begin{array}{l}\text { Обслуговує більше мільярда користувачів. } \\
\text { Загальний обсяг платежів сягає } 118 \text { трильйо- } \\
\text { нів юанів }\end{array}$ & $\begin{array}{l}\text { Дочірня компанія групи Alibaba, яка воло- } \\
\text { діє найбільшою китайською платформою } \\
\text { цифрових платежів }\end{array}$ \\
\hline Lufax & $\begin{array}{l}\text { Підтримується великими інтернет- } \\
\text { компаніями, такими як Ant Group, WeBank та } \\
\text { Tencent Licaitong. }\end{array}$ & $\begin{array}{l}\text { Провідна платформа персональних фінан- } \\
\text { сових послуг, яка працюючи за допомогою } \\
\text { бізнес-моделі "Нub and Spoke", на основі } \\
\text { застосування передових технологій інтег- } \\
\text { рує онлайн- та офлайн-ресурси в обслуго- } \\
\text { вуванні клієнтів. }\end{array}$ \\
\hline East Money & $\begin{array}{l}\text { Професійний фінансовий засіб масової інфо- } \\
\text { рмації в Інтернеті, що надає цілодобово фі- } \\
\text { нансову інформацію та котирування світового } \\
\text { фінансового ринку. }\end{array}$ & $\begin{array}{l}\text { Займається цінними паперами, електрон- } \\
\text { ною комерцією, наданням фінансових да- } \\
\text { них, обслуговуванням Інтернет-реклами. }\end{array}$ \\
\hline JD Digits & $\begin{array}{l}\text { Сформував провідну екосистему фінансових } \\
\text { технологій у Китаї для підприємств та спожи- } \\
\text { вачів; випустив низку інноваційних продуктів } \\
\text { (Jingbaobei, Baitiao, JD Wallet, JD Finance APP, } \\
\text { Xiaojinku, JD Microcredit тa Xiaobailicai) }\end{array}$ & $\begin{array}{l}\text { Бізнес-метою JD Digital Technology визна- } \\
\text { чено об’єднання галузей з цифровими тех- } \\
\text { нологіями, допомога в оцифруванні бізне- } \\
\text { су, запровадженні штучного інтелекту. }\end{array}$ \\
\hline WeBank & $\begin{array}{l}\text { Найбільший у світі цифровий банк, що вико- } \\
\text { ристовує у своїй діяльності технології } \\
\text { BigData, штучний інтелект, блокчейн, хмарні } \\
\text { технології для надання комплексних фінансо- } \\
\text { вих послуг приватним особам, малому й сере- } \\
\text { дньому бізнесу. }\end{array}$ & $\begin{array}{l}\text { WeBank не має фізичних відділень чи філій і } \\
\text { не покладається на майнові гарантії. Для } \\
\text { управління своєю бізнес-моделлю максима- } \\
\text { льно повно й активно використовує іннова- } \\
\text { ційні інформаційні технології. }\end{array}$ \\
\hline
\end{tabular}


Закінчення табл. 3

\begin{tabular}{|c|c|c|}
\hline 1 & 2 & 3 \\
\hline Hundsun & $\begin{array}{l}\text { Має понад } 7000 \text { партнерів, у тому числі у сфері } \\
\text { наукових досліджень і розробок. }\end{array}$ & $\begin{array}{l}\text { Провідний постачальник фінансового } \\
\text { програмного забезпечення та мережевих } \\
\text { послуг у Китаї. }\end{array}$ \\
\hline $\begin{array}{l}\text { Hithink } \\
\text { RoyalFlush }\end{array}$ & $\begin{array}{l}\text { За допомогою своїх цифрових та прикладних пла- } \\
\text { тформ, інструментів фінансового аналізу, систем } \\
\text { онлайн-торгівлі та програмних рішень в основно- } \\
\text { му займається збором і наданням фінансової ін- } \\
\text { формації корпораціям, фінансовим операторам, } \\
\text { приватним інвесторам, уряду та фізичним особам. }\end{array}$ & $\begin{array}{l}\text { Представляє собою інформаційну мере- } \\
\text { жу, яка використовує у своїй діяльності } \\
27 \text { технологій для вебсайту. }\end{array}$ \\
\hline $\begin{array}{l}\text { Suning } \\
\text { Finance }\end{array}$ & $\begin{array}{l}\text { Надає малому та середньому бізнесу якісні } \\
\text { портфелі фінансових продуктів, включаючи } \\
\text { оплату, фінансування ланцюжка поставок, спо- } \\
\text { живче фінансування, управління інвестиціями, } \\
\text { страхування та ін. }\end{array}$ & $\begin{array}{l}\text { У своїй діяльності використовує перева- } \\
\text { жно такі технології: біометрична іденти- } \\
\text { фікація; контроль ризиків на основі «ве- } \\
\text { ликих даних»; інтелектуальний } \\
\text { маркетинг; роботи-консультанти; фінан- } \\
\text { сова хмара. }\end{array}$ \\
\hline ZhongAn & $\begin{array}{l}\text { Включає Jack Ма від Alibaba, Pony Ма від } \\
\text { Tencent та Mingzhe Ма від Ping An Insurance. }\end{array}$ & $\begin{array}{l}\text { Компанія, які надає свої послуги зі стра- } \\
\text { хування виключно в онлайн-форматі. }\end{array}$ \\
\hline
\end{tabular}

Джерело: складено авторами на основі [25-33].

Висновки та пропозиції. Активне впровадження інформаційних технологій у діяльність фінансових установ забезпечує провідним країнам світу можливість утримання високих місць у світових рейтингах і високих конкурентних позицій на міжнародному ринку фінансових послуг. Передусім це обгрунтовується зростанням якісного рівня послуг, які надаються фінансовими установами країни, підвищенням їх швидкості, точності, транспарентності та надійності. Окрім цього, інноваційні технології спроможні робити фінансові операції більш зрозумілими та зручними для споживачів.

До ключових передумов імплементації інформаційних технологій у діяльність фінансових інституцій можна віднести такі: 1) висококонкурентне середовище, що мотивує фінансові установи до постійного пошуку інноваційних ідей, нових бізнес-моделей, підтримки FinTech-стартапів; 2) наявність підтримки наукових досліджень з боку держави та бізнес-сектору; 3) розвиненість інформаційної інфраструктури та інвестування в її вдосконалення; 4) фінансова грамотність громадян та їх готовність до опанування нових технологій; 5) висока інноваційна культура в суспільстві.

На наше переконання, одним із питань, яке найгостріше стоїть на порядку денному сучасних фінансових установ, є захист інформації. У країнах Європейського Союзу цьому питанню приділяється особлива увага як на законодавчому, так і на технічному рівні. Наприклад, наразі тривають роботи над винайденням аксесуарів (спеціальних чохлів) для пластикових карток, які убезпечать їх власників від шахраїв і несанкціонованого зчитування інформації, необхідної для активації вбудованих в них чіпів з даними для здійснення безконтактної оплати. Не менш актуальною є проблема забезпечення кібербезпеки, що вимагає формування дієвих механізмів протидії кібератакам, а також розробки інноваційних інформаційних технологій захисту фінансових систем та інформації про суб'єктів ринку фінансових послуг. Саме в цьому вбачаємо перспективи подальших досліджень за цієї темою.

\section{Список використаних джерел}

1. Top 10 Largest fintech companies in Europe. 2020. URL: https://medium.com/businesschief/top-10-largest-fintech-companies-in-europe-b47de0f3cafc.

2. Портал інформації про банки Німеччини DeutschesKonto.org. Рахунок №26 та картка MasterCard. URL: https://www.deutscheskonto.org/ru/number26. 
3. Інвестиційний портал InVenture. Німецький онлайн-банк N26 увійшов в число найдорожчих європейських «єдинорогів». 2019. URL: https://inventure.com.ua/news/world/nemeckijonlajn-bank-n26-voshel-v-chislo-samyh-dorogih-evropejskih-edinorogov.

4. Офіційний сайт OakNorth. URL: https://www.oaknorth.com.

5. Офіційний сайт Monzo. URL: https://monzo.com.

6. Офіційний сайт Funding Circle. URL: https://www.fundingcircle.com/uk.

7. Cavus, N. \& Chingoka, D., N., C. (2015). Information technology in the banking sector: Review of mobile banking. Global Journal of Information Technology, 5(2), pp. 62-70.

8. Як банки використовують AI та Big Data для створення нових сервісів. 2020. URL: .https://www.everest.ua/yak-banky-vykorystovuyut-ai-ta-big-data-dlya-stvorennya-novyh-servisiv.

9. Швидкий Blockchain як ядро нових банківських технологій. 2020. URL: https://guland.com.ua/ kryptovalyuta/blockchain/blokcheyn-i-banky.htm.

10. Електронний журнал «Bloomberg». Заміна роботами співробітників у Швеції. 2018. URL: https://www.finanz.ru/novosti/aktsii/krupneyshiy-bank-shvecii-reshil-zamenit-robotami-6tysyach-sotrudnikov-1027409738.

11. How Five Robots Replaced Seven Employees at a Swiss Bank. URL: https://www.bloomberg.com/ news/articles/2018-05-04/how-five-robots-replaced-seven-employeesat-a-swiss-bank.

12. Роботи наступають: У США банк найняв штучний інтелект на посаду копірайтера. URL: https://www.5.ua/nauka/roboty-nastupaiut-u-ssha-bank-nainiav-shtuchnyi-intelekt-na-posadukopiraitera-197384.html.

13. Банки: майбутнє за хмарними рішеннями. 2016. URL: https://ioblik.com/uk/ documentation/banki_buduschee_za_oblachnymi_resheniyami.

14. United Nations Conference on Trade and Development. URL: https://unctad.org.

15. Сербина О. Г., Пономар В. В. Тенденції розвитку мобільного банкінгу в Україні. Молодий вчений. 2014. № 3. URL: http://molodyvcheny.in.ua/files/journal/2014/3/14.pdf

16. Top 10 Biggest Fintech Companies In America 2020. URL: https://www.forbes.com/sites/ jeffkauflin/2020/02/12/the-10-biggest-fintech-companies-in-america-2020/?sh=6ee40b781259.

17. Офіційний сайт Ripple. URL: https://ripple.com.

18. Не будь как Robinhood: разбираем интерфейсы брокерских приложений. 2020. URL: https://vc.ru/services/143007-ne-bud-kak-robinhood-razbiraem-interfeysy-brokerskih-prilozheniy.

19. Дают второй шанс и бесплатную кредитку. Как работает необанк Chime. 2021. URL: https://vc.ru/finance/203375-dayut-vtoroy-shans-i-besplatnuyu-kreditku-kak-rabotaet-neobank-chime

20. Офіційний сайт Plaid. URL: https://plaid.com/eu.

21. Орлов Д. (2012) Применение азиатских стандартов качества и инновационной практики при создании в россии инвестиционной базы для продвижения на рынок высокотехнологичных банковских продуктов и услуг. URL: http://rasia.com/files/DmitriyOrlov.pdf.

22. Как искусственный интеллект используется в реальном бизнесе. 2017. URL: https://www.azoft.ru/blog/iskusstvennyj-intellekt-v-realnom-biznese.

23. China's Financial Services Industry Is Banking on AI. 2020. URL: https://syncedreview.com/2020/01/04/chinas-financial-services-industry-is-banking-on-ai.

24. IT investment in the banking industry occupies the first place in the financial industry, and AI is heavily deployed to compete for the future of intelligent financial services. Smart Week Report Core Edition. URL: https://mp.weixin.qq.com/s/S4-RjpoijBno4e66XUNvDw.

25. Top 10 companies in China in 2020. URL: https://www.chinainternetwatch.com/31367/topfintech-companies.

26. Офіційний сайт Lufax. URL: https://www.lufaxholding.com/about/index.

27. Британське агентство новин та постачальник даних про фінансові ринки Reuters. East Money Information Co.,Ltd. URL: https://www.reuters.com/companies/300059.SZ.

28. Платформа для пошуку бізнес-інформації про приватні та державні компанії Crunbase. East Money Information. URL: https://www.crunchbase.com/organization/east-money-information.

29. WeBank. China Internet Watch. 2020. URL: https://www.chinainternetwatch.com/company/ webank.

30. Офіційний сайт Hundsun. URL: https://www.hundsun.com/en/about.aspx\#a1. 
ФІНАНСОВІ РЕСУРСИ: ПРОБЛЕМИ ФОРМУВАННЯ ТА ВИКОРИСТАННЯ

31. Hithink royalflush information Network Co.,Ltd. Електронний журнал Marketscreener. URL: https://www.marketscreener.com/quote/stock/HITHINK-ROYALFLUSH-INFORM-7660572/company.

32. Офіційний сайт Suning Finance. URL: https://www.suningholdings.com/cms/ snFinancialServices/index.htm.

33. Zhongan. Електронний журнал «China Internet Watch». 2020. URL: https:/www.chinainternetwatch.com/company/zhongan.

\section{References}

1. Top 10 Largest fintech companies in Europe. (n.d.). Retrieved 14.01.2021 https://medium.com/business-chief/top-10-largest-fintech-companies-in-europe-b47de0f3cafc.

2. Portal informatsii pro banky Nimechchyny DeutschesKonto.org. Rakhunok №26 ta kartka MasterCard [Information portal about German banks DeutschesKonto.org. Account №26 and MasterCard] (n.d.). Retrieved 20.01.2021 https://www.deutscheskonto.org/ru/number26.

3. Investytsiinyi portal InVenture. Nimetskyi onlain-bank N26 uviishov v chyslo naidorozhchykh yevropeiskykh «iedynorohiv» [InVenture investment portal. The German online bank N26 has become one of the most expensive European "unicorns"] (n.d.). Retrieved 21.01 .2021 https://inventure.com.ua/news/world/nemeckij-onlajn-bank-n26-voshel-v-chislo-samyh-dorogihevropejskih-edinorogov.

4. Official site OakNorth. (n.d.). Retrieved 03.02.2021 https://www.oaknorth.com.

5. Official site Monzo. (n.d.). Retrieved 03.02.2021 https://monzo.com.

6. Official site Funding Circle. (n.d.). Retrieved 03.02.2021 https://www.fundingcircle.com/uk/

7. Cavus, N. \& Chingoka, D., N., C. (2015). Information technology in the banking sector: Review of mobile banking. Global Journal of Information Technology, 5(2), pp. 62-70.

8. Iak banky vykorystovuiut AI ta Big Data dlia stvorennia novykh servisiv [How banks use AI and Big Data to create new services] (n.d.). Retrieved 20.01.2021 https://www.everest.ua/yak-bankyvykorystovuyut-ai-ta-big-data-dlya-stvorennya-novyh-servisiv.

9. Fast Blockchain as the core of new banking technology [Fast Blockchain as the core of new banking technology] (n.d.). Retrieved 16.01.2021 https:/guland.com.ua/kryptovalyuta/blockchain/ blokcheyn-i-banky.htm.

10. Elektronnyi zhurnal «Bloomberg». Zamina robotamy spivrobitnykiv u Shvetsii [Bloomberg ezine. Replacement of employees in Sweden] (n.d.). Retrieved 19.01.2021 https://www.finanz.ru/novosti/aktsii/krupneyshiy-bank-shvecii-reshil-zamenit-robotami-6-tysyachsotrudnikov-1027409738.

11. How Five Robots Replaced Seven Employees at a Swiss Bank. (n.d.). Retrieved 20.01.2021 from https://www.bloomberg.com/news/articles/2018-05-04/how-five-robots-replaced-seven-employees-at-aswiss-bank.

12. Roboty nastupaiut: U SShA bank nainiav shtuchnyi intelekt na posadu kopiraitera [Robots are coming: In the US, the bank has hired artificial intelligence for the position of copywriter] (n.d.). Retrieved 10.01.2021 from https://www.5.ua/nauka/roboty-nastupaiut-u-ssha-bank-nainiav-shtuchnyiintelekt-na-posadu-kopiraitera-197384.html.

13. Banky: maibutnie za khmarnymy rishenniamy [Banks: the future of cloud solutions] (n.d.). Retrieved 18.01.2021 https://ioblik.com/uk/documentation/banki buduschee za oblachnymi resheniyami.

14. United Nations Conference on Trade and Development. (n.d.). Retrieved 20.01.2021 https://unctad.org/.

15. Serbyna O. H., Ponomar V. V. (2014) Tendentsii rozvytku mobilnoho bankinhu v Ukraini. [Trends in the development of mobile banking in Ukraine] Molodyi vchenyi - Young scientist, (3), Retrieved 22.01.2021 http://molodyvcheny.in.ua/files/journal/2014/3/14.pdf.

16. Top 10 Biggest Fintech Companies In America. 2020. (n.d.). Retrieved 03.02.2021 https://www.forbes.com/sites/jeffkauflin/2020/02/12/the-10-biggest-fintech-companies-in-america2020/?sh=6ee40b781259.

17. Official site Ripple. (n.d.). Retrieved 20.01.2021 https://ripple.com.

18. Ne bud kak Robinhood: razbyraem ynteresi brokerskykh prylozhenyi [Don't be like Robinhood: we disassemble the interfaces of brokerage applications] (n.d.). Retrieved 19.01.2021 https://vc.ru/services/143007-ne-bud-kak-robinhood-razbiraem-interfeysy-brokerskih-prilozheniy. 
19. They give you a second chance and a free credit card. How neobank Chime works [They give you a second chance and a free credit card. How neobank Chime works] (n.d.). Retrieved 20.01.2021 https://vc.ru/finance/203375-dayut-vtoroy-shans-i-besplatnuyu-kreditku-kak-rabotaet-neobank-chime

20. Official site Plaid. (n.d.). Retrieved 20.01.2021 https://plaid.com/eu.

21. Orlov D. (2012) Prymenenye azyatskykh standartov kachestva y ynnovatsyonnoi praktyky pry sozdanyy $v$ Possyy ynvestytsyonnoi bazi dlia prodvyzhenyia na rinok visokotekhnolohychnkh bankovskykh produktov y usluh [Application of Asian quality standards and innovative practices when creating an investment base in Russia for promoting high-tech banking products and services to the market] Retrieved 02.02.2021 http://rasia.com/files/DmitriyOrlov.pdf.

22. How artificial intelligence is used in real business [How artificial intelligence is used in real business] (n.d.). Retrieved 20.01.2021 https://www.azoft.ru/blog/iskusstvennyj-intellekt-v-realnombiznese.

23. China's Financial Services Industry Is Banking on AI. (n.d.). Retrieved 20.01.2021 https://syncedreview.com/2020/01/04/chinas-financial-services-industry-is-banking-on-ai.

24. IT investment in the banking industry occupies the first place in the financial industry, and AI is heavily deployed to compete for the future of intelligent financial services. Smart Week Report Core Edition. (n.d.). Retrieved 20.01.2021 https://mp.weixin.qq.com/s/S4-RjpoijBno4e66XUNvDw.

25. Top 10 companies in China in 2020. (n.d.). Retrieved 20.01.2021 https://www.chinainternetwatch.com/31367/top-fintech-companies.

26. Official site Lufax. (n.d.). Retrieved 20.01.2021 https://www.lufaxholding.com/about/index.

27. British news agency and financial markets data provider Reuters [British news agency and financial markets data provider Reuters] East Money Information Co.,Ltd. (n.d.). Retrieved 20.01.2021 https://www.reuters.com/companies/300059.SZ.

28. Platforma dlia poshuku biznes-informatsii pro pryvatni ta derzhavni kompanii Crunbase [A platform for finding business information about private and public companies Crunbase] East Money Information. (n.d.). Retrieved 20.01.2021 https://www.crunchbase.com/organization/east-moneyinformation.

29. WeBank. China Internet Watch. 2020. (n.d.). Retrieved 20.01.2021 https://www.chinainternetwatch.com/company/webank.

30. Official site Hundsun. URL: https://www.hundsun.com/en/about.aspx\#a1.

31. Hithink royalflush information Network Co.,Ltd. Electronic journal Marketscreener. (n.d.). Retrieved 20.01.2021 https:/www.marketscreener.com/quote/stock/hithink-royalflush-inform7660572 /company.

32. Official site Suning Finance. (n.d.). Retrieved 20.01.2021 https://www.suningholdings.com/ cms/snFinancialServices/index.htm.

33. Zhongan. Electronic journal China Internet Watch. (n.d.). Retrieved 20.01.2021 https://www.chinainternetwatch.com/company/zhongan.

\footnotetext{
Холявко Наталія Іванівна - доктор економічних наук, доцент, Національний університет «Чернігівська політехніка» (вул. Шевченка, 95, м. Чернігів, 14035, Україна).

Kholiavko Nataliia - Doctor of Economics, Associate Professor, Chernihiv Polytechnic National University (95 Shevchenka Str., 14035 Chernihiv, Ukraine).

E-mail: nateco@meta.ua

ORCID ID: https://orcid.org/0000-0003-2951-7233

Researcher ID: G-6951-2014

Scopus Author ID: 56912328200

Колоток Марія Олегівна - здобувачка вищої освіти, Національний університет «Чернігівська політехніка» (вул. Шевченка, 95, м. Чернігів, 14035, Україна).

Kolotok Mariia - Student, Chernihiv Polytechnic National University (95 Shevchenka Str., 14035 Chernihiv,Ukraine).

E-mail: masha_kolotok@ukr.net
}

\footnotetext{
Холявко Н., Колоток М. Інформаційні технології в роботі зарубіжних фінансових установ. Проблеми і перспективи економіки та управління. 2021. № 1(25). С. 117-126.
} 